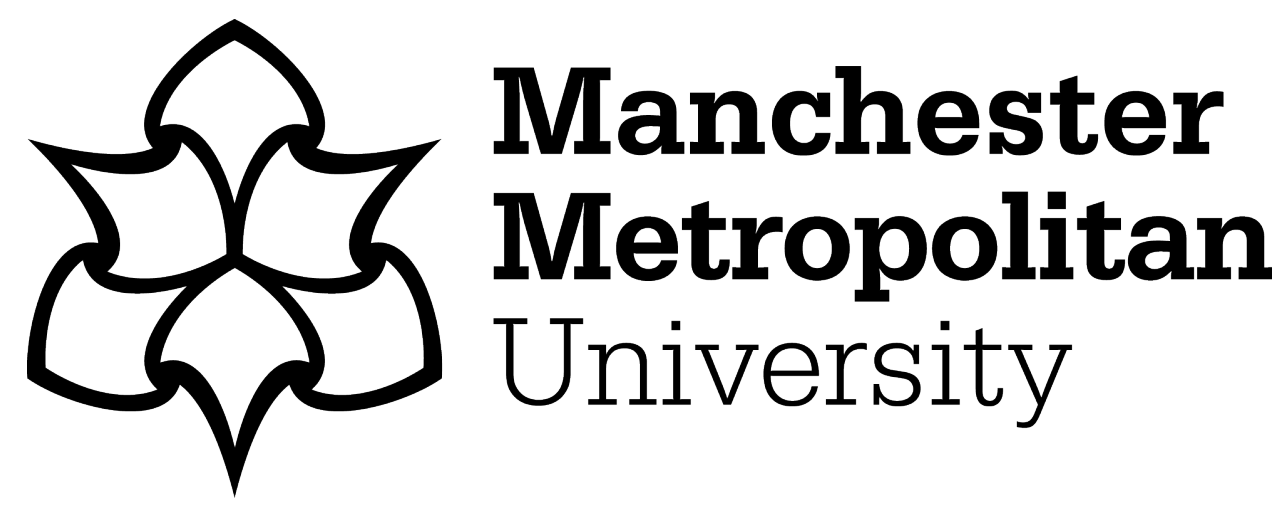

Giladi, P (2015) Hegel's Therapeutic Conception of Philosophy. Hegel Bulletin, 36 (2). pp. 248-267. ISSN 2051-5375

Downloaded from: https://e-space.mmu.ac.uk/620916/

Publisher: Cambridge University Press

DOI: https://doi.org/10.1017/hgl.2015.20

Please cite the published version 


\section{Hegel's Therapeutic Conception of Philosophy}

The aim of this paper is to argue that Hegel has a therapeutic conception of philosophy, and also to argue that in significant respects this anticipates the classical pragmatist position, which is also interpreted as offering a therapeutic approach. In the first section, I introduce Hegel's views on how theoretical reasoning has an important connection with practical life. I argue that this important connection between theoretical reason and the practical establishes Hegel as a member of the therapeutic tradition - broadly conceived. My focus in section II of the paper is on the relation between Hegelian therapy and Wittgenstein's quietistic approach. I conclude my discussion of Hegel's therapeutic conception of philosophy in section III, by arguing that Hegelian therapy has much in common with classical pragmatist metaphilosophy, which I also take to involve a therapeutic approach. ${ }^{1}$

One of the most well-known features of ancient philosophy, starting with Socrates and through to the post-Aristotelian philosophical traditions of Epicureanism, Stoicism, and Pyrrhonism, is the idea that philosophy must play a role in helping us to lead the good life. ${ }^{2}$ In contrast to the predominantly more academically-oriented conception of philosophy that one finds in current philosophical discourse, ancient philosophers adopted a more expansive conception of philosophical practice, where even when these philosophers employed techniques recognisably similar to those of contemporary philosophy, figures such as Plato and Epicurus appeared to rationalise the use of such techniques by markedly therapeutic goals. ${ }^{3}$ For example, Socrates links conceptual analysis with the moral improvement of himself and his interlocutors, cf. Apology 38a.

However, whilst ancient philosophy can be understood to emphasise the link between philosophical reflection and personal/communal flourishing, ${ }^{4}$ such an explicit connection

\footnotetext{
${ }^{1}$ I would like to thank Bob Stern and Paul Raekstad for their invaluable feedback on previous drafts of this paper.

2 See Nussbaum (1994) for an excellent analysis of the idea of philosophy as therapeutic in the Hellenistic tradition. See also Sorabji (2000) for an excellent analysis of the development of the therapeutic tradition from Stoicism to Christian Neoplatonism.

${ }^{3}$ I am using 'therapeutic' here in a broad sense, such that it links to the good life / the flourishing life. Recent contemporary discussions of philosophy having a necessarily therapeutic dimension to conceptual reflection include the following works: Gitsoulis (2007), Harré (2008), and Fischer (2011a, 2011b, 2011c).

${ }^{4}$ Of course, one must stress that the notion of philosophy as therapeutic is not unique to European philosophy, as the commitment to regarding conceptual reflection as having a eudaimonistic and cathartic function is made
} 
between the theoretical and the practical is not a feature that one would prima facie associate with the Kantian and post-Kantian philosophical tradition. On the contrary, they appear to be focused on more technical debates in metaphysics and epistemology, involving claims regarding synthetic a priori knowledge, the objective validity of the Categories, the ideality of the finite, and so on. Furthermore, there seems to be good reason to suppose that philosophy in general hardly appears to be therapeutic, given how technical issues such as the problem of vagueness or of other minds have been the focal points of debate in academic philosophy. Nonetheless, despite the appearance of some lack of interest in drawing connections between philosophical reflection and the good life, ${ }^{5}$ I will argue that there is in fact every reason to suppose that the German Idealists were staunchly committed to drawing such a connection. I wish to focus in particular on Hegel's views on the relationship between theoretical reason and practical life. Specifically, I would like to draw attention to how Hegel came to adopt a therapeutic approach, where Hegel's therapeutic conception of philosophy sets itself the therapeutic goal of helping us feel 'at home in the world'. 6

Hegel's views on the relationship between theoretical reason and practical life are partly motivated by his dissatisfaction with Kant's understanding of how exactly our conceptual capacities enable us to think about the world from our specifically human perspective, which Hegel precisely sees as preventing us from feeling 'at home in the world'. What Hegel finds unattractive about Kant's understanding of categorial concepts (and conceptual form) is his worry about subjectivism, where because the categories are 'only our thoughts', we then seem to ourselves to be cut off from the fundamental nature of reality, with all the disquiet that must lead to, Kant's consoling words notwithstanding. ${ }^{7}$ Another interesting dimension to Hegel's charge of subjectivism ${ }^{8}$ is that there is good reason to suppose that Hegel chastised Kant for accounting for human discursivity independently of its historical and social contexts.

explicit in Buddhist and non-Buddhist philosophical traditions in the East. For a very useful guide to how eastern philosophical schools regarded philosophy to be therapeutic, see Ganeri \& Carlisle (2010).

${ }^{5}$ What I have claimed could lead one to suppose that most philosophers turn out to be part of the therapeutic tradition, so that the term 'therapeutic tradition' appears to be vacuous. However, my point is not to divide up the tradition into camps, but merely to show that more philosophers can be put within the tradition than may appear prima facie.

${ }^{6}$ The only paper that I have come across that explicitly discusses Hegel's metaphilosophical commitments to a therapeutic model of enquiry is Quante (2004). See the addition to Section 4 of the Introduction to the Philosophy of Right for Hegel's first explicit use of the idea of at-homeness-in-the-world.

${ }^{7}$ Hegel's charge is best expressed in Encyclopaedia, §41z: 67-68.

8 The topic of Hegel's rejection of transcendental idealism is one of most important issues in Kant-Hegel scholarship. I can only briefly discuss the relevant issues here, because a proper discussion of Hegel's critique would take us well outside the desired focus of this paper. For more in depth interpretations and assessments of Hegel's rejection of transcendental idealism, see the following works: Ameriks (1985), Bird (1987), Stern (2002), Kreines (2006, 2008), Sedgwick (2012), Förster (2012), and Bowman (2013). Of course, this is no by means whatsoever an exhaustive list of scholarly papers on the subject. 
As a result, Hegel thinks of the Kantian subject as a res cogitans: Kant overlooked the nature of the human subject as a res ambulans and a res dormiens, which goes alongside its rational nature, once again leaving us estranged, this time from ourselves. To put the worry another way, Hegel criticises Kant for having failed to properly surpass Cartesianism. ${ }^{9}$ Ultimately, then, Hegel's fundamental worry about Kantianism, that transcendental idealism is too narrow and too restricted, can be seen to be as much about the question of how we can come to be 'at home in the world', as it is about technical questions and puzzles, such as the problem of synthetic a priori knowledge or disputes concerning the nature of space.

Given that Hegel's principal philosophical concern is with establishing how one can come to be at home in the world, this may shed light on why Hegel insists that philosophy has an important role to play in the Bildung of man as opposed to being an esoteric practice with little or no relevance to our ultimate well-being. ${ }^{10}$ In making this claim, we can begin to see how Hegel conceives of philosophy as a therapeutic discipline. To understand this in detail, we need to look more closely at the relationship between Kant and Hegel on this issue.

Despite Hegel's misgivings about transcendental idealism, there is something about Kant's metaphilosophical commitments that Hegel finds not just to be important but also largely correct. Hegel seems to think that Kant conceives of philosophy as having an edifying or normative/existential function: as I understand Kant, the critique of theoretical reason would involve a transformation of not just our cognitive practices but also how we understand the role of thought in our lives. By understanding ourselves in a new way, as laid out by the Copernican turn in the discipline, we realise that our cognitive constitution does not merely serve as mechanical conditions to experience things in certain ways - we also realise that the kind of cognitive constitution we have determines the type of phenomenological relation we have to our cognitive environment. For example, our categorial structure is based on concepts such as causality, necessity, unity, and substance. These concepts do not just enable us to experience a world sans phrase, but they also serve to enable us to experience the world in a specific way: being endowed with concepts provides human beings to represent the world as a phenomenologically robust environment: we are acquainted with a world that has nomological properties and objects that persist through change. In other words, one of Kant's central insights is the notion that being endowed with a capacity of conceptual thought and reflection does not merely enable human beings to experience things, but crucially also enables human beings to see the world from a particular

\footnotetext{
${ }^{9}$ See Taylor (1972) for a related claim.

${ }^{10}$ Such insistence can best be found in the general tone of the Preface to the Phenomenology of Spirit.
} 
perspective. This perspective, moreover, is the foundation for the superstructure of how we go about our daily lives. Hegel can be seen as finding Kant's insight into how thought has this normative/existential function to be fundamentally important.

This view is supported by Hegel's discussion of Kant's Antinomies of Pure Reason, where he claims that Kant's insights are some of "most important and deepest advances in philosophy in the modern period" (EL: §48). Of course, Hegel is also very critical of Kant's treatment of the Antinomies. However, why Hegel thinks Kant's treatment of the Antinomies is dissatisfying is not because Kant simply got things wrong; rather, Hegel's critique is based on his view that Kant failed to draw more Antinomies from the structure of thought. This is what Hegel means by claiming that Kant is restricted by "finite categories". For Hegel, what Kant ought to have done is notice how "antinomy finds itself ... in all objects of all kinds, in all representations, concepts and ideas" (EL: §48). In other words, Kant appears to have failed to develop his important insights.

Hegel's means of 'completing' this Kantian programme is his notion of the forms of consciousness. The reason why the forms of consciousness serve this particular function is that they properly bring out the existential significance of the antinomial conflict. This goes beyond the purely theoretical goal of highlighting the ubiquity of contradiction in discursive thought, because such a goal is still abstract despite being systematic. Rather what Hegel wants to achieve is to illustrate how antinomial conflict manifests itself in experience and how antinomial conflict actually impacts on our ways of representing objects, ourselves, and the world as a whole. Such a project is the only one that has justified claims to being a philosophical science. The way in which Hegel conceives of thought as impacting on both our cognitive and practical lives is by conceiving of a form of consciousness as amounting to a Weltanschauung - a way of seeing the world from a particular perspective. To put this very briefly, every form of consciousness that the phenomenological subject traverses through from Sense-Certainty to Absolute Knowing - is a different way of representing oneself and the world for the purposes of achieving 'at homeness' in the world. In other words, the dialectic of human thought through its phenomenological development is the historical illustration of our attempts to find a way of looking at ourselves and our world that enables us to flourish. As such, the connection between theoretical reason and practical life lies in how whatever form of consciousness one adopts determines how one will act in the world: if one thinks about oneself as radically separate from one's environment, then such a worldview will result in the subject being unable to properly interact with others, viz. the struggle for 
recognition; or if one fails to conceive of social institutions as being capable of reform and structural revision, then such a worldview will result in the subject finding that social institution incapable of enabling societal improvement and development, viz. Hegel's analysis of Antigone. For Hegel, the drama of consciousness in its constant flux from one form of consciousness to another is equivalent to consciousness desperately trying to find a way of being at peace with various philosophical problematics, such as the relationship between universality and particularity, identity and difference, desire and duty, scepticism and dogmatism, hope and despair, and the state and the individual. The task of finding a way of being at peace with these antinomial conflicts effectively amounts to finding a way of enabling human beings to flourish. As such, for Hegel, there is compelling reason to regard his speculative philosophy and phenomenological method as making him a member of the therapeutic tradition broadly conceived.

As we saw earlier, the therapeutic tradition broadly conceived goes back to the Socratic schools. However, since the mid- $20^{\text {th }}$ century this tradition has been more narrowly associated with a particular conception of therapy, which is known as 'quietism'. ${ }^{11}$ In what follows, I shall argue Hegel conceives of philosophy as therapeutic and that he has a nuanced form of philosophical quietism.

Wittgenstein is usually credited with having pioneered philosophical quietism. ${ }^{12}$ Broadly speaking, quietism is the methodological view that philosophers should aim to eliminate, as opposed to solve, philosophical problems and return us to a state of intellectual peace. ${ }^{13}$ To see what this means, we need to understand various sections of Wittgenstein's Philosophical Investigations. In $§ 125$, Wittgenstein writes:

It is the business of philosophy, not to resolve a contradiction by means of a mathematical or logico-mathematical discovery, but to make it possible for us to get a clear view of the state of mathematics that troubles us: the state of affairs before the contradiction is resolved.

\footnotetext{
11 Philosophers who are usually regarded as philosophical quietists include Wittgenstein, Gilbert Ryle, J. L. Austin, Norman Malcolm, Richard Rorty, and John McDowell. One could also arguably include Jennifer Hornsby as a member of the quietist tradition.

12 See Lesses (2002) and Mitsis (2002) for useful discussions of Epicurus's proto-quietism on the subject of the fear of death. The broad quietist telos of attaining intellectual peace is made even more explicit in Pyrrhonian scepticism, which stresses the ideal of ataraxia - a tranquil state of mind and complete freedom from disturbance. See Nussbaum (1994), Machuca (2006), and Striker (2010) for useful discussions of the Pyrrhonist concept of ataraxia.

${ }^{13}$ For a useful discussion of philosophical quietism, see McDowell (1994).
} 
According to Wittgenstein, philosophical problems (which he defines in $\S 111$ as "deep disquietudes") are not meant to be solved in the sense that philosophers aim to find a satisfactory answer to the question that causes us aporias. Rather, these problems are meant to be eliminated or undermined by understanding the framework that gives rise to the disquietude in the first place. In other words, unlike the problem-solving model of the philosophical enterprise, which grants legitimacy to various philosophical questions, quietism denies that various philosophical questions are legitimate, and as such rejects the idea that they should be answered, and that one should even raise these issues in the first place. ${ }^{14}$ As Wittgenstein writes, "[eventually] the philosophical problems should completely disappear. The real discovery is the one ... that gives philosophy peace, so that it is no longer tormented by questions which bring itself in question" (PI: $§ 133)$. So, for example, a quietist solution to the Problem of Interaction in philosophy of mind and the Placement Problem in metaphilosophy would look something like this: the question 'How is it possible for the mind and the body to interact with one another?' should not be asked, because it assumes that mental phenomena and physical phenomena are fundamentally distinct to begin with, where it is precisely this dualist framework gives rise to disquietude here. Once we understand that this dualist framework is the cause of the aporia, we must provide a more cogent framework which will give us intellectual peace. The Placement Problem, ${ }^{15}$ however, is more complicated to deal with: the question 'How is it possible to place normativity in nature, given that normative phenomena appear to be outside the scope of the natural?' should not be

\footnotetext{
14 Michael Quante provides a very helpful framework for discussing Hegel and the therapeutic model of enquiry: Quante distinguishes between therapeutic and 'constructive' philosophy of various differing forms. In its narrowest sense, the conception of philosophy as therapeutic claims that the function of philosophy solely consists in curing misunderstandings that are engendered by philosophical mistakes. In a wider sense, the conception of philosophy as therapeutic claims that the function of philosophy consists in curing misunderstandings that are engendered by both the mistakes of philosophers and the mistakes of nonphilosophers. With regard to 'constructive' philosophy, which Quante regards as equivalent to conceiving of philosophy as a problem-solving discipline, Quante draws four further distinctions: in the pejorative sense, this model of philosophy creates the problems that necessarily require therapeutic treatment by mistaking philosophical problematics for real/genuine problems; in its narrow sense, constructive philosophy provides solutions for real problems within common sense that pose genuine threats to the good life; in its wider sense, constructive philosophy goes further in wanting to provide a philosophical framework to support the assumptions of common sense, even when those assumptions are not the cause for various aporias; and in its revisionary sense, constructive philosophy aims to replace common sense, which it regards to be entirely bankrupt.

${ }^{15}$ As Huw Price (2004) suggests, the Placement Problem can be expressed in the following way: (1) All reality is ultimately natural reality; (2) whatever one wishes to admit into natural reality must be placed in natural reality; (3) moral facts, mathematical facts, universals, laws of nature, mental states, and so on do not seem admissible into natural reality; (4) therefore, if they are to be placed in nature, they must be forced into a category that does not seem appropriate for their specific characters, and if they cannot be placed in nature, then they must be either dismissed as non-genuine phenomena or at best regarded as second-rate phenomena.
} 
asked, because the question is in and of itself flawed, and the question leaves itself open to two fundamentally dissatisfying answers. ${ }^{16}$ In the first case, the question is based on a mischaracterisation of normativity; in the latter case, our framework for answering the question is restricted to either bald naturalism or rampant Platonism. ${ }^{17}$ Once we understand that a problematic characterisation of normativity and a poor conceptual framework are the cause of the aporia, we can then be in a position to improve our framework by adopting liberal naturalism in the hope that this position will give us intellectual peace. ${ }^{18}$

Of course, my outline of these quietist solutions is meant to be very sketchy, for my outline is aimed at revealing the methodology of quietism, rather than being directed at addressing those two philosophical issues. As Wittgenstein wrote in the Philosophical Investigations, "[ $\mathrm{t}]$ he philosopher's treatment of a question is like the treatment of an illness" (§255). In other words, the methodology of quietism roughly follows the approach of curing some kind of ailment or disease. Just as a physician will first diagnose the condition and then administer some cure, the quietist philosopher must first diagnose the relevant intellectual problem and then work out a cogent means of curing the aporia.

For Wittgenstein, the diagnosis of our maladies philosophiques is that we enter into conceptual difficulties by misusing ordinary language. The 'metaphysical' use of ordinary linguistic terms is the cause of our philosophical anxieties. What this signifies is that philosophers are the source of problematics, not because philosophers aim at deliberately muddying conceptual waters, but rather because philosophical speculation appears to inevitably conflict with our everyday linguistic practices. As mentioned previously, Wittgenstein claims that conceptual problems emerge from running up against the limits of language. Now, whilst the Tractarian Wittgenstein would have been inclined to remedy the problem by trying to improve or cleanse ordinary language, the later Wittgenstein seems to think that such a view is ultimately too philosophical. Rather, the cure for our cognitive maladies consists in understanding how ordinary language works and how we must stick with ordinary language. And what that linguistic enterprise involves is returning us to a form of life where we reflect non-philosophically. This, in other words, means that the true philosopher is the one who realises the futility and nonsense of philosophical enquiry. Only by becoming quietists can we achieve the Tractarian goal of kicking away the ladder and saying only what can be said. Philosophy, then, for the Wittgensteinian quietist eschews any

\footnotetext{
${ }^{16}$ See Rorty (2010) for an engaging and typically provocative discussion of naturalism and quietism.

${ }^{17}$ See Macarthur (2008) for an excellent discussion of quietist responses to the nature-normativity debate.

${ }^{18}$ See Giladi (2014) for a discussion of this topic.
} 
positive doctrines - rather than being concerned with defending substantive theories about the good or the true, it is concerned with exposing misuses of language.

Hegel, of course, is no Wittgensteinian and would almost certainly balk at the idea of eschewing any positive doctrines and admonishing philosophical reflection in favour of a retreat to ordinary consciousness and its binary categories of thought. But, given this, it seems difficult to maintain, let alone motivate, the case that he has a quietist conception of philosophical therapy. However, such a difficulty only arises if we think of quietism exclusively in Wittgensteinian ways. If we recall our previous definition of philosophical quietism, quietism is the methodological view that philosophers should aim to eliminate, as opposed to solve, philosophical problems and return us to a state of intellectual peace. Crucially, if one is inclined to eliminate/dissolve philosophical problems rather than solving them head-on, one can do so by either adopting Wittgenstein's diagnostic and therapeutic approach or by adopting a Hegelian diagnostic and therapeutic approach. Namely, one can dissolve the relevant problematic either by finding it to be the result of a misuse of ordinary language and therefore recommend a return to common sense; or by finding it to be the result of a limited and non-dialectical conceptual structure and therefore recommend a dialectical critique of the relevant philosophical stance in question.

The following passage from the Phenomenology probably best illustrates Hegel's diagnostic approach:

The more that conventional opinion holds that the opposition between the true and the false is itself fixed and set, the more that it customarily expects to find itself in either agreement or in contradiction with any given philosophical system, and, if so, then in any explanation of such a system, the more it will merely see the one or the other. It does not comprehend the diversity of philosophical systems as the progressive development of truth as much as it sees merely contradiction within that diversity. The bud disappears when the blossom breaks through, and one might say that the former is refuted by the latter. Likewise, by virtue of the fruit, the blossom itself may be declared to be a false existence of the plant, since the fruit emerges as the blossom's truth as it comes to replace the blossom itself. These forms are not merely distinguished from each other, but, as incompatible with each other, they also supplant each other. However, at the same time their fluid nature makes them into moments of an organic unity within which they are not only not in conflict with each other. Rather, one is equally as necessary as the other, and it is this equal necessity which alone constitutes the life of the whole. However, in part, contradiction with regard to a philosophical system does not usually comprehend itself in this way, and, in part, the consciousness which apprehends the contradiction generally neither knows how to free the contradiction from its one-sidedness, nor how to sustain it as free-standing by taking cognizance of its reciprocally necessary moments, which themselves take shape as conflicts and as apparent incompatibilities. (PS: 2-3) 
For Hegel, an important symptom of philosophical disquietude is how we tend to regard certain ideas to be fundamentally irreconcilable with one another. And we think in that way due to having a non-dialectical understanding of negation. Our ordinary (or natural) understanding of negation is one which sees the negation of a position as the complete obliteration of that position. This, in turn, serves as the grounds for the strength of the Law of Non-Contradiction. However, whilst our ordinary understanding of negation has both plausibility and practical value, the problem with this framework is not that the framework is false or incoherent, but rather that the framework cannot adequately make sense of the notion of development and growth. Hegel's concern, then, with negation is with the philosophical aporias we run into when we reflect on the history of philosophical enquiry and how we try to understand the movements from one philosophical tradition to the next. We remain paralysed by these kinds of aporias, if we reflect only from the ordinary perspective of negation. Therefore, the remedy for this is to improve our philosophical understanding. For Hegel, specifically, one way of successfully accomplishing such a task is by distinguishing between reason (Vernunft) and understanding (Verstand). Unlike Kant, Hegel does not claim that "these terms ... designate completely independent functions or faculties. Reason is simply the necessary result of the immanent movement of the understanding". ${ }^{19}$ In other words, reason is in some sense part of understanding, insofar as reason is a form of analytic explanation, but in another sense, reason is distinct from understanding, insofar as reason is also a "form of holistic explanation, which shows how all finite things are parts of a wider whole". ${ }^{20}$ For Hegel, the principal advantage of drawing this distinction between reason and understanding is that we can be in a position to not be wrapped up in the various dualisms which are the inevitable consequence of reflecting only from the perspective of understanding, i.e. purely analytical forms of reflection. What reason provides consciousness with is the means to avoid the pitfalls of dualisms and the problems of analysis by thinking dialectically, i.e. by drawing distinctions yet establishing interconnectedness to a whole.

This particular brand of quietism is perhaps best explicated by Hegel in this famous passage from his Lectures on Fine Art:

What man seeks in this situation, ensnared here as he is in finitude on every side, is the region of a higher, more substantial, truth, in which all oppositions and contradictions in the finite can find their final resolution, and freedom its full satisfaction. This is the region of absolute, not finite, truth. The highest truth, truth as such, is the resolution of

\footnotetext{
${ }^{19}$ F. C. Beiser, 2005: 164.

${ }^{20}$ Ibid., p. 165.
} 
the highest opposition and contradiction. In it validity and power are swept away from the opposition between freedom and necessity, between spirit and nature, between knowledge and its object, between law and impulse, from opposition and contradiction as such, whatever forms they make take. Their validity and power as opposition and contradiction is gone. Absolute truth proves that neither freedom by itself, as subjective, sundered from necessity, is absolutely a true thing nor, by parity of reasoning, is truthfulness to be ascribed necessity isolated and taken by itself. The ordinary consciousness, on the other hand, cannot extricate itself from this opposition and either remains despairingly in contradiction or else casts it aside and helps itself in some other way. But philosophy enters into the heart of the self-contradictory characteristics, knows them in their essential nature, i.e. as in their one-sidedness not absolute but selfdissolving, and it sets them in the harmony and unity which is truth. To grasp this Concept is the task of philosophy. (LA I: 99-100)

The arguments Hegel gives in this engaging passage - namely that the task of philosophy is to lead our ways of understanding all aspects of our world away from purely dualistic and oppositional ways of thinking, and to enable us to reflect on the intelligibility of both difference and unity in our world - serve as a powerful critique of quietist strategies that aim to provide philosophical cures by means of effectively ignoring the philosophical nature of certain problematics. As he writes, only a dialectical conception of philosophical enquiry and a dialectical conceptual resource can provide the conditions for achieving 'full satisfaction'. What this means is that the kind of quietist strategy advocated by Wittgensteinians may very well provide some satisfaction to enquirers, but ultimately that sense of intellectual disquietude is hollow and is in fact disquieting more than substantially therapeutic. The kind of intellectual approach that can provide 'full satisfaction' is one which explicitly tarries with the negative - this is because only that model of enquiry and its corresponding conceptual resources make concerted efforts to unify conceptual contraries in a nuanced way to remove the initial and powerful image of opposition and to move us to seeing them as constituting harmonious determinations of a complex whole.

By now, it should be reasonably clear that one can make a good case for conceiving of Hegel as a particular kind of philosophical quietist. In what follows, I would like to explain how exactly Hegel's brand of philosophical therapy - his variety of quietism - can and should be understood as anticipating crucial features of classical pragmatist metaphilosophy. However, before moving on to this issue, it is important that we first have a basic grip on what exactly one means by 'pragmatism'. 
III

Hilary Putnam has identified four characteristics of pragmatism: ${ }^{21}$ the rejection of scepticism; the commitment to fallabilism; the rejection of strict dualisms such as the distinction between nature and freedom; and what he has called "the primacy of practice". ${ }^{22}$ For the purposes of this paper, I want to focus on the latter two characteristics. A locus classicus for rejecting strict dualisms is William James's famous discussion of the conflict between the 'toughminded"23 and the 'tender-minded'. As Christopher Hookway writes, "[ $t]$ he tough-minded have an empiricist commitment to experience and going by 'the facts', while the tenderminded have more of a taste for a priori principles which appeal to the mind. The tenderminded tend to be idealistic, optimistic and religious, while the tough-minded are normally materialist, pessimistic and irreligious. The tender-minded are 'free-willist' and dogmatic; the tough-minded are 'fatalistic' and sceptical". ${ }^{24}$ According to James, one cannot resolve this dispute by favouring one or the other. ${ }^{25}$ In other words, we cannot claim that empirical and natural science trump religiosity and Romanticism, and we cannot claim that religiosity and Romanticism trump empirical and natural science. To use John McDowell's terminology, neither bald naturalism nor rampant Platonism will do the required work. Instead, we must find a 'mediating philosophy' to reconcile the scientific image with the manifest image, to reconcile "empiricist epistemic responsibility with moral and religious optimism". ${ }^{26}$ Such a particular type of philosophy is needed, because only a mediating philosophy can properly

\footnotetext{
${ }^{21}$ See Putnam (1994a).

${ }^{22}$ See Putnam (1994b).

${ }^{23}$ A particularly vivid portrayal of the tough-minded is James's discussion of Ernest Renan and Emile Zola:
}

"Both are athirst for the facts of life, and both think the facts of human sensibility to be of all facts the most worthy of attention. Both agree, moreover, that sensibility seems to be there for no higher purpose - certainly not ... for the sake of bringing mere outward rights to pass and frustrating outward wrongs ... under the pages of both there sounds incessantly the hoarse bass of vanitas vanitatum, omnia vanitas, which the reader may hear, whenever he will, between the lines. No writer of this French romantic school has a word of rescue from the hour of satiety with the things of life - the hour in which we say 'I take no pleasure in them' - or from the hour of terror at the world's vast meaningless grinding, if perchance such hours should come. For terror and satiety are facts of sensibility like any others; and at their own hour they reign in their own right. The heart of the romantic utterances, whether poetical, critical, or historical, is this inward remedilessness, what Carlyle calls this far-off whimpering of wail and woe. And from this romantic state of mind there is absolutely no possible theoretic escape. Whether, like Renan, we look upon life in a more refined manner, as a romance of the spirit; or whether, like the friends of M. Zola we ... prefer to be cynical, and call the world a 'roman experimental' on an infinite scale - in either case the world appears to us potentially as what the same Carlyle one called it, a vast, gloomy, solitary Golgotha and mill of death". (TWTB: 133-134)

${ }^{24}$ C. Hookway, http://plato.stanford.edu/entries/pragmatism/\#PraPra

${ }^{25}$ Echoing Fichte on the oscillation between dogmatism and idealism, James also thinks that one tends to be stuck in either one camp or the other.

${ }^{26}$ Hookway, http://plato.stanford.edu/entries/pragmatism/\#PraPra 
represent a "method for settling metaphysical disputes that might otherwise be interminable". 27

An important question to ask now is how we should understand James's notion of 'settling metaphysical disputes that might otherwise be interminable'. As I see it, there is no reason to suppose that James's idea of settling a dispute that appears to be interminable should not be thought of in terms of the broad philosophical quietist strategy of dissolving problematics to enable us achieve a sense of intellectual peace. ${ }^{28}$ Given this, we now need to explain why only a mediating philosophy is able to dissolve problematics and enable us to achieve a sense of intellectual peace. To do so, let us briefly consider two instances of apparently interminable disputes: (i) the mind-world dualism; and (ii) the individual-society relation.

Regarding (i), what was partly characteristic of early modern philosophy was the idea that there was a fundamental gap between mind and world - between the subjects of experience and the objects of experience. The picture of empirical reality as presented by that tradition is of a realm of separate and inert objects, which requires us to first understand each object individually and then determine its connectedness with other objects. Not only that, but the mind is also fundamentally separate from the world of experience. We are passive recipients of raw and non-conceptual representational content, which we then process in order to have an epistemic grip on the world. However, in contrast to the Enlightenment's portrayal of minds as mirrors of nature, James (as well as Peirce and Dewey in differing ways) aimed to dissolve the strict distinction between mind and world not by collapsing one into the other but rather by reconceiving the content of experience as well as the relation between the subject of experience and their cognitive environment. Experience provides a rational and intelligible structure constituted by directly perceivable ontologically complex, determinate objects. And to be a thinking subject is not to be a disembodied res cogitans that is separate from the world and is little more than a cognitive voyeur. Rather, to be a thinking subject is to be an embodied being embedded in the world. As Matthew Ratcliffe writes, "[w]e do not

\footnotetext{
${ }^{27}$ W. James, 1907: 28.

${ }^{28}$ Of course, for James, this must not be understood in purely theoretical terms: the real value of dissolving problematics and establishing a new and nuanced conceptual framework consists in the social and political benefits of adopting pragmatist commitments. For example, James's caustic criticisms of 'intellectualism' - a form of enquiry which is essentially dissociated from the exigencies of practice - aim at illustrating the potentially disastrous social and political consequences of such a form of enquiry.
} 
philosophise as disembodied loci of rational thought, stripped of our practical, affective, bodily attunement to things". ${ }^{29}$ And as James writes himself:

Pretend what we may, the whole man within us is at work when we form our philosophical opinions. Intellect, will, taste, and passion co-operate just as they do in practical affairs ... ${ }^{30}$

Philosophical enquiry, for James, must not be conceived of in the way that early modern rationalism characterised philosophical enquiry. While the Cartesian project of pure enquiry aimed to provide substantive conceptions of knowledge by avoiding corporeality and sociality, James conceived of pragmatism as the philosophical school of thought to provide substantive conceptions of truth and knowledge by embedding all human capacities in the world. As he famously wrote, the most pressing problem with early modern rationalism is that it "seems too buttoned-up and white-chokered and clean-shaven a thing to speak for the vast slow-breathing unconscious Kosmos with its dread abysses and its unknown tides". 31 Such a critique appears to be characteristic of opponents of Cartesianism, ranging from the post-Kantian idealists, through Merleau-Ponty, Heidegger, Wittgenstein, to Rorty. ${ }^{32}$ Though all these philosophers differ from one another in important respects, they are all committed to the view that the mind-world relation must be understood in terms of cognitive intimacy rather than cognitive voyeurism. And to do so necessarily involves emphasising how thinking is necessarily bound up with direct bodily engagement with things and implicit social relations with other rational agents in the world. Once we frame the concepts of mind and world in this way, then the dispute is dissolved and we are no longer troubled by the philosophical anxieties arising from the aporias caused by the strict dualist framework.

Regarding (ii), the classical pragmatist approach to the dualism of society and the individual is one which finds the framework that gives rise to oscillating between authoritarianism and anarchism or conservatism and liberalism to be the source of the philosophical malady. For example, Dewey is critical of classical liberalism for conceiving of the individual as prior to society and that social institutions must therefore be organised in such a way so as to serve the interests of pre-societal individuals. In the same way that the early modern tradition conceived of the phenomenological relation between mind and world as one of fundamental separation, Dewey claims that classical liberalism is a practical

\footnotetext{
${ }^{29}$ M. Ratcliffe, 2011: 126.

${ }^{30}$ W. James, 1956: 92.

${ }^{31}$ James, 1912: 277-8.

${ }^{32}$ See Taylor (1972) for an excellent discussion of this topic.
} 
exemplification of "the most pervasive fallacy of philosophical thinking", 33 namely dividing up and separating phenomena into strict distinctions from one another. Contra this picture of the individual and its corresponding conception of freedom, Dewey aims to eliminate the philosophical pathology of a radical separation of the individual and social institutions by advocating a nuanced political holism:

Liberalism knows that an individual is nothing fixed, given ready-made. It is something achieved, and achieved not in isolation but with the aid and support of conditions, cultural and physical: - including in "cultural", economic, legal and political institutions as well as science and art. ( $L W 11: 291)$

As with the dissolution of the mind/world dualism, the individual and society are no longer conceived of as fundamentally separate from another, pace the classical liberal picture according to which one's freedom is understood exclusively negatively as autonomy from any external constraint on one's ability to pursue such-and-such. Rather, according to Dewey's political holism, we understand freedom in terms of a positive capacity to realise oneself. Crucially, moreover, such realisation can only be achieved by conceiving of individuality as necessarily embedded in a reflective and social environment. To put this more simply, where the previous philosophical traditions separated mind and world and individuality and sociality, the classical pragmatists hoped to make mind and world and individuality and sociality interdependent with one another. In shifting our way of thinking from separating phenomena to understanding the fundamental interdependency between phenomena which appear to be conceptual contraries, we dissolve the dispute and are then able to have a sense of peace.

Thus far, we have seen how classical pragmatists took their novel ideas to be therapeutic: they dissolve philosophical problematics by rejecting the conceptual framework that gives rise to the problematic in the first place. And by dissolving the problematic and advocating a nuanced conception of the philosophical issue in question, they hoped to return enquirers to a state of philosophical quietude. Crucially, though, one should not think that the classical pragmatists are best interpreted in a Wittgensteinian mode, even though they share the broad idea of dissolving philosophical problems: unlike Wittgenstein, the classical pragmatists' remedy for intellectual aporia involves a substantive philosophical improvement rather than a

${ }^{33}$ J. Dewey, 1981-1990 5: 5. 
return to a pre-philosophical form of life. ${ }^{34}$ Such substantive philosophical improvement, to use Dewey's expression, involves 'getting over' philosophical problems stemming from premodern conceptual frameworks, to the extent that philosophy would directly contribute to social and political development. For example, the fundamental concern of Peirce's Pragmatic Maxim and a fortiori his variety of pragmatism is to establish human flourishing by properly understanding the metaphysical picture of reality and properly understanding the nature and methods of enquiry. As Hookway writes, "Peirce's work in ethics is motivated by a desire to explain the possibility of adopting the life of science as he understands it". ${ }^{35}$ This is elaborated by Paul Forster, who claims that "[o]n [Peirce's] view, human beings are not cogs in a vast cosmic mechanism, but rather are free, creative agents capable of transforming the world through the active realisation of intelligent ideals". ${ }^{36}$ What is at stake when one puts forward philosophical theories or even when one does philosophy is not merely whether or not one attains sufficiently good levels of representational accuracy. Peirce is not particularly interested in this purely theoretical mode of cognitive activity. Rather, what matters for Peirce is "an ultimate, impartial, binding and rational framework for the organisation and fulfilment of human potential". ${ }^{37}$ The explanation for why Peirce was so explicitly opposed to nominalism and its philosophical correlates is that nominalism and its philosophical correlates are obstacles to the organisation and fulfilment of human potential: nominalism seeks to restrict enquiry and by doing so, nominalism prevents us from actualising our rational capacities. And because our rational capacities fail to be fully realised by nominalism, the possibility of us flourishing does not obtain.

It should be clear that Hegel's brand of therapy anticipates a crucial feature of classical pragmatist metaphilosophy, given how he explicitly claimed that the task of philosophy is to dissolve and overcome strict dualisms and binary categories of thought. ${ }^{38}$

\footnotetext{
${ }^{34}$ It is worth noting that Peirce's notion of 'critical common-sensism' does not appear to advocate a return to a pre-philosophical form of life even though Peirce is supportive of common sense, see EP 2:346-353; CP 5.439452; CP 5.505-525; CP 5.498-499; EP 2:432-433.

${ }^{35}$ C. Hookway, 2013: 192.

${ }^{36}$ P. Forster, 2011: 245.

${ }^{37}$ Ibid., p. 246.

${ }^{38}$ By establishing such a connection between Hegel and the classical pragmatists, there is good reason to see why exactly Dewey wrote of the "permanent deposit" Hegel had left on his philosophical commitments, cf. $L W$ 5: 154. There is also good reason to suppose James's explicit hostility to Hegel may in fact be rather misplaced. For had James (and Peirce to some extent) had really known Hegel, rather than understood Hegel via the distorted view of him presented by F. E. Abbot, Royce and the British Idealists, James (and Peirce to some extent) may have had a far more positive attitude to Hegel. See Stern (2009) for further on Hegel's reception by Peirce and James.
} 
This conveniently leads to understanding the ultimate thrust of Hegel's brand of therapy and how exactly it anticipates classical pragmatist metaphilosophical commitments. What is the value to be gained by dissolving problematics and rejecting strict dualisms? One can recall previously that a characteristic of pragmatism is the Primacy of Practice. I take this idea to refer to conceiving of a philosophical endeavour as being significant if and only if that philosophical endeavour has demonstrable effects on us and the world we inhabit. ${ }^{39}$ The diagnostic part of what can be called pragmatic therapy, as developed respectively by Hegel and the classical pragmatists, has two purposes: the first is to locate and establish the cause of our intellectual and existential disquietude; and the second is to determine which questions are worth worrying about in the first instance. Consequently, the recommended therapeutic programme offered by Hegel and the classical pragmatists - though differing in important ways - is specifically designed to foster and engender a genuine sense of autonomy and human bien être. Both Hegel and the classical pragmatists are committed to seeing human beings as amphibians of sorts ${ }^{40}$ - we are intellectual and affective; we are rational and also capable of irrationality; and we are animals that are self-interpreting. But the kind of rationality we exhibit when we develop our second nature and cultural agency is one which recognises the need to avoid transcending the empirical world in an effort to cope with the variety of unpleasant and harmful things in the world. We recognise the deficiency of being too tender-minded. Crucially, though, this does not mean that human mindedness either adopts a depressing and pessimistic stance or a jocund Panglossian attitude to the strife we find all around us. On the contrary, it means that we are compelled to find genuinely meaningful and practical reasons to conceive of the world as rationally intelligible, not because the intelligible structure of the world illustrates that we can know everything about the world if we exercise our conceptual capacities in the best possible way, but because our rationality enables us to think and feel that we can make sense of things. However, we can only make sense of things and thus feel at home in the world if we are provided with the freedom to conduct our enquiries with epistemic and moral responsibility. Hence, for both the Hegelian and classical pragmatist conception of therapy, there is no separation of our philosophic lives from our social/political/daily lives, and that the concept of abstract philosophical ideas which have no concrete significance to our efforts of feeling at home in the world must be committed to the flames.

\footnotetext{
${ }^{39}$ To put this more crudely, a philosophical endeavour is significant if and only if that endeavour has clear impact on our lives and our environment.

${ }^{40}$ See Pinkard (2012) for further on Hegel's amphibian analogy.
} 
References

Ameriks, K. 1985. 'Hegel's Critique of Kant's Theoretical Philosophy'. Philosophy and Phenomenological Research 46: 1-35.

Beiser, F. C. 2005. Hegel. New York \& London: Routledge.

Bird, G. 1987. 'Hegel's Account of Kant's Epistemology in the Lectures on the History of Philosophy', in S. Priest (ed.) Hegel's Critique of Kant. Oxford/Brookfield, VM: Gregg Revivals/Oxford University Press.

--- 2006. The Revolutionary Kant: A Commentary on the 'Critique of Pure Reason'. Chicago and La Salle, ILL: Open Court.

Bowman, B. 2013. Hegel and the Metaphysics of Absolute Negativity. Cambridge: Cambridge University Press.

De Caro, M. and Voltolini, A. 2010. 'Is Liberal Naturalism Possible?', in M. De Caro and D. Macarthur (eds.) Naturalism and Normativity. New York, NY: Columbia University Press.

Dewey, J. 1981-1990. The Later Works, 17 volumes, J. Boydston (ed.) Carbondale: Southern Illinois University Press (abbreviated here as LW, followed by volume number).

Fischer, E. 2011a. 'Diseases of the Understanding and the Need for Philosophical Therapy'. Philosophical Investigations 34: 22-54.

--- 2011b. 'How to Practise Philosophy as Therapy: Philosophical Therapy and Therapeutic Philosophy'. Metaphilosophy 42: 49-82.

--- 2011c. Philosophical Delusion and its Therapy: Outline of a Philosophical Revolution. London and New York: Routledge.

Forster, P. 2011. Peirce and the Threat of Nominalism. Cambridge: Cambridge University Press.

Förster, E. 2012. The Twenty Five-Years of Philosophy. B. Bowman (trans.) Cambridge, MA: Harvard University Press.

Ganeri, J. \& Carlisle, C. (eds.) 2010. Philosophy as Therapeia. Cambridge: Cambridge University Press.

Giladi, P. 2014. 'Liberal Naturalism: The Curious Case of Hegel'. International Journal of Philosophical Studies 22: 248-270.

Gitsoulis, C. 2007. 'The Moral Dimension of Wittgenstein's Philosophical Method'. Analysis and Metaphysics (Special Issue on Wittgenstein) 6: 452-467. 
Gunnarsson, L. 2010. 'The Philosopher as Pathogenic Agent, Patient and Therapist: The Case of William James, in J. Ganeri \& C. Carlisle (eds.) Philosophy as Therapeia. Cambridge: Cambridge University Press.

Guyer, P. 1987. Kant and the Claims of Knowledge. Cambridge: Cambridge University Press. Harré, R. 2008. 'Grammatical Therapy and the Third Wittgenstein'. Metaphilosophy 39: 484491.

Hegel, G. W. F. 1970. Philosophy of Nature (Part Two of the Encyclopaedia of Philosophical Sciences), M. J. Petry (trans.) 3 vols, London: George Allen and Unwin.

--- 1975. Lectures on Fine Art. T. M. Knox (trans.) 2 vols. Oxford: Oxford University Press.

--- 1977a. Phenomenology of Spirit. A. V. Miller (trans.) Oxford: Oxford University Press.

--- 1977b. The Difference Between Fichte's and Schelling's System of Philosophy. H. S. Harris \& W. Cerf (trans.) Albany, NY: State University of New York Press.

--- 1991b. The Encyclopaedia Logic: Part 1 of the Encyclopaedia of Philosophical Sciences. T. F. Geraets, W. A. Suchting, and H. S. Harris (trans.) Indianapolis: Hackett.

--- 1995. Lectures on the History of Philosophy. E. S. Haldane (trans.) Lincoln: University of Nebraska Press.

Hookway, C. 2013. The Pragmatic Maxim. Oxford: Oxford University Press.

--- "Pragmatism", The Stanford Encyclopaedia of Philosophy, Edward N. Zalta (ed.), URL = $<$ http://plato.stanford.edu/archives/win2013/entries/pragmatism/>.

James, W. 1907. Pragmatism: A New Name for some Old Ways of Thinking. Cambridge, MA: Harvard University Press.

--- 1912. Essays in Radical Empiricism. New York: Longmans, Green and Co.

--- 1956. The Will to Believe and Other Essays in Popular Philosophy. New York: Dover Publications.

Kant, I. 1998. Critique of Pure Reason. P. Guyer \& A. W. Wood (trans.) Cambridge: Cambridge University Press.

Kreines, J. 2006. 'Hegel's Metaphysics: Changing the Debate'. Philosophy Compass 1.5: 466-480.

--- 2008. 'Hegel: Metaphysics without Pre-Critical Monism'. Bulletin of the Hegel Society of Great Britain 57/58: 48-70.

Leiter, B. ed. 2004. The Future of Philosophy. Oxford: Clarendon Press.

Lesses, G. 2002. 'Happiness, Completeness, and Indifference to Death in Epicurean Ethical Theory'. Apeiron 35: 57-68. 
Macarthur, D. 2008. 'Pragmatism, Metaphysical Quietism, and the Problem of Normativity'. Philosophical Topics 36: 193-209.

Machuca, D. 2006. 'The Pyrrhonist's ataraxia and philanthrôpia' Ancient Philosophy 26: 111-139.

McDowell, J. 1994. Mind and World. Cambridge, MA: Harvard University Press.

Mitsis, P. 2002. 'Happiness and Death in Epicurean Ethics' Apeiron 35: 41-55.

Moore, A. W. 2012. The Evolution of Modern Philosophy: The Evolution of Modern Metaphysics: Making Sense of Things. Cambridge: Cambridge University Press.

Neta, R. 2007. 'Review of De Caro and Macarthur (eds.), Naturalism in Question'. Philosophical Review 116: 657-62.

Nussbaum, M. 1994. The Therapy of Desire: Theory and Practice in Hellenistic Ethics. Princeton: Princeton University Press.

Peirce, C. S. 1931-1958. Collected Papers of Charles Sanders Peirce, 8 vols. C. Hartshorne, P. Weiss, and A. W. Burks (eds.) Vols. 1-6 edited by C. Harteshorne and P. Weiss, 19311935; vols. 7-8 edited by A. W. Burks, 1958. Cambridge, MA: Harvard University Press.

--- 1992 and 1998. The Essential Peirce, 2 vols. N. Houser, C. Kloesel, and the Peirce Edition Project (eds.) Bloomington, IA: Indiana University Press.

Pinkard, T. 2012. Hegel's Naturalism: Mind, Nature, and the Final Ends of Life. Oxford: Oxford University Press.

Cooper, J. M. (ed.) 1997. Plato: Complete Works. Indianapolis: Hackett.

Price, H. 2004. 'Naturalism without Representationalism', in M. De Caro and D. Macarthur (eds.) Naturalism in Question. Cambridge, MA: Harvard University Press.

Putnam, H. 1994a. Words and Life. Cambridge: Harvard University Press

--- 1994b. Pragmatism. Oxford: Blackwell.

Quante, M. 2004. 'Spekulative Philosophie als Therapie' in Hegels Erbe, H. von Christoph Halbig ed., M. Quante and L. Siep (eds.) Suhrkamp Taschenbuch.

Ratcliffe, M. 2011. 'Stance, feeling and phenomenology'. Synthese 178: 121-130.

Redding, P. 2007. Analytic Philosophy and the Return of Hegelian Thought. Cambridge: Cambridge University Press.

Rorty, R. 2010. 'Naturalism and Quietism', in M. De Caro and D. Macarthur (eds.) Naturalism and Normativity. New York, NY: Columbia University Press.

Sedgwick, S. 2012. Hegel's Critique of Kant. Oxford: Oxford University Press. 
Sorabji, R. 2000. Emotion and Peace of Mind: From Stoic Agitation to Christian Temptation. Oxford: Clarendon Press.

Stern, R. 2002. Routledge Philosophy Guidebook to Hegel and the 'Phenomenology of Spirit'. London: Routledge.

--- 2009. Hegelian Metaphysics. Oxford: Oxford University Press.

Striker, G. 2010. 'Pyrrho and Early Pyrrhonism', in R. Bett (ed.) The Cambridge Companion to Ancient Scepticism. Cambridge: Cambridge University Press.

Taylor, C. 1972. 'The Opening Arguments of the Phenomenology', in A. MacIntyre (ed.) Hegel: A Collection of Critical Essays. Notre Dame: Notre Dame University Press.

Wittgenstein, L. 1961. Tractatus Logico-Philosophicus. D. F. Pears \& B. F. McGuiness trans. New York \& London: Routledge.

--- 2009. Philosophical Investigations, 4th edition. P.M.S. Hacker \& J. Schulte (eds.) \& (trans.) Oxford: Wiley-Blackwell. 